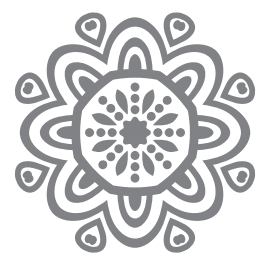

\title{
PERAN TEKNOLOGI DI DUNIA ISLAM
}

\author{
Aan Rukmana, MA \\ (Dosen Falsafah dan Agama Universitas Paramadina)
}

\begin{abstract}
Islam since the beginning of its birth has encouraged science. The command "iqra" is authentic evidence of how Islam loves science. This evidence shows that Islam has a major contribution to the development of science, including technology in it. This paper attempts to explain the contribution of Islam to technological development from the classical Islamic period to the current era. ICT is a contemporary problem facing Muslims. There are two choices, whether to reject ICT or accept it. This paper focuses on how Muslims can accept ICT for developing the Islamic scholarship
\end{abstract}

Keywords: ICT, Investigo Dei, Iqra, Ayat Kauniyyah, Ayat Naqliyyah

\section{Latar Belakang}

Memasuki abad ke-21 ini umat manusia memasuki sebuah era yang tidak pernah terbayangkan sebelumnya. Era di mana informasi menjadi sangat berlimpah ruah dan dapat diakses dari manapun dan oleh siapapun. Tentu perkembangan ini tidak dapat lepas dari pemikiran umat manusia sejak masa renaisans, abad ke 16 Masehi di daratan Eropa. Sejak masa itu, kehidupan manusia yang sebelumnya berada di dalam bayang-bayang otoritas agama-khususnya kalangan gereja, mulai berpikir kritis untuk melakukan aktivitas berpikir yang lebih independen, sehingga arah sejarah kehidupan umat manusia ditentukan oleh manusia itu sendiri sebagai subjek sejarah, bukan oleh otoritas yang berada di luar manusia. ${ }^{1}$

Memasuki abad ke-18 terjadi tiga revolusi penting bagi perjalanan ilmu pengetahuan manusia, yaitu terjadinya protestanisme sebagai kritik atas orto-

1 Akhyar Yusuf Lubis, Filsafat Ilmu Klasik Hingga Kontemporer. Jakarta: Rajawali Pers, 2016, hal. $111-136$. 
doksi kalangan gereja Katolik Roma, revolusi politik di Prancis yang mengajarkan ajaran liberte, egalite, fraternite (kebebasan, persamaa dan persaudaraan) yang menginspirasi kemudian lahirnya sistem politik modern dan revolusi industri di Inggris yang mendorong masifnya dunia industri yang berakibat pada lahirnya negara Inggris sebagai imperium terkuat pada masa itu. Akibatnya era kolonialisme pun lahir, sehingga daratan Eropa termasuk wilayah Inggris berubah menjadi negara-negara kuat yang menjajah negara-negara lainnya.

Secara perlahan, ilmu pengetahuan pun kian berkembang pesat, sehingga teknologi canggih pun saling berkejaran di antara negara-negara kuat yang menjajah tersebut. Alfin Toffler (1928 - 2006), seorang futurolog dari Amerika Serikat pernah meramalkan bahwa kehidupan umat manusia yang ditandai dengan kemajuan ilmu pengetahuan, akan melewati tiga fase gelombang sejarah (the third wave), yaitu (1) gelombang masyarakat agraris (pertanian) yang dari 8000 SM - $1700 \mathrm{M}$, (2) gelombang masyarakat industru dengan rentang waktu dari 1700 - $1970 \mathrm{M}$ dan (3) gelombang masyarakat informasi dengan rentang waktu dari 1979 - sekarang. ${ }^{2}$ Jadi dapat disimpulkan bahwa era informasi saat ini yang ditandai dengan kemajuan Teknologi Informasi (IT) yang semakin pesat, merupakan keniscayaan logis sebagai tanda kemajuan ilmu pengetahuan umat manusia.

\section{Al-Qur'an dalam Pengembangan Sains dan Teknologi}

Islam sejak awal kemunculannya sudah menganjurkan umatnya untuk mendalami ilmu pengetahuan. ${ }^{3}$ Perintah tersebut disampaikan langsung kepada Nabi Muhammad SAW dengan perintah membaca (iqra!) alam serta segala isinya. Sebagaimana termaktub di dalam Surat al-'Alaq (1):

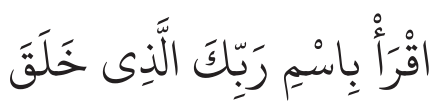

Artinya: "Bacalah dengan menyebut nama Tuhanmu yang menciptakan."

Perintah membaca tersebut merupakan titik pangkal (turning point) dari kebangkitan sebuah peradaban luhur yang kelak akan mendorong perkemban-

${ }^{2}$ Alvin Toffler, The Third Wave, USA: Bantam Books, 1980, hal. 56.

${ }^{3}$ Di dalam al-Qur'an materi terkait 'aql terulang sebanyak 49 kali. Semua tertulis dalam bentuk fi'il mudhari', kecuali hanya satu yang tidak, dan itu pun tersambung dengan wawu jamaah yang artinya tampil dalam bentuk ta'qilun atau ya'qilun. Kata kerja ta'qilun terulang sebanyak 24 kali dan kata kerja ya'qilun sebanyak 22 kali. Sedangkan, kata kerja 'aqala, na'qilu dan ya'qilu masing-masing terdapat satu kali. Nampak di sini al-Qur'an sangat menekankan pentingnya umat Islam mendalami ilmu pengetahuan. Baca Yusuf Qardhawi, Al-Quran Berbicara tentang Akal dan Ilmu Pengetahuan. Terj. Abdul Hayyie al-Kattani \& Irfan Salim. Jakarta: Gema Insani Press, 1998, hal. 19. 
gan ilmu pengetahuan dan teknologi. Sejak saat itu umat Islam, dapat dikatakan, sebagai masyarakat yang gemar mengkaji alam semesta serta segala isinya, di samping untuk mempelajari hukum alam yang terdapat di dalamnya juga untuk mencari jejak-jejak Tuhan (investigo dei) yang terdapat di alam raya. ${ }^{4}$

Meskipun al-Qur'an mendorong umatnya untuk mentradisikan membaca sebagai kunci dan bekal hidup di atas muka bumi, namun hal tersebut tidaklah dimaksudkan untuk mendorong lahirnya ilmu pengetahuan semata, lebih dari itu untuk mendorong umat Islam agar dapat semakin mensyukuri nikmat Allah yang sudah diberikan kepada manusia. Maka tidaklah heran jika sejak saat itu muncul generasi Islam yang ahli di berbagai bidang ilmu pengetahuan dan pada saat yang bersamaan juga dikenal sebagai orang-orang yang saleh dan beriman kepada Allah SWT.

Pengembangan ilmu pengetahuan bagi seorang Muslim, termasuk teknologi di dalamnya, merupakan bagian dari ketaatan kepada perintah Allah SWT. Islam tidak pernah mengenal jargon ilmu untuk ilmu, apalagi ilmu untuk kerusakan umat manusia. Ilmu pengetahuan dikembangkan oleh umat Islam untuk kebaikan umat manusia. Ilmu pengetahuan terletak di bawah sinar kebijaksanaan Ilahiah. Scientia tunduk di bawah cahaya sapientia (kearifan). Ilmu pengetahuan menjadikan seseorang semakin dekat dengan Sang Pencipta. Semakin pandai seseorang, semakin ia dapat merasakan kebesaran Allah SWT, sebaliknya semakin bodoh seseorang, semakin berat bagi dirinya untuk merasakan kehadiran Allah, Sang Pencipta segenap alam semesta.

Bagi seorang Muslim yang taat terdapat dua ayat sebagai bekal dalam mengarungi hidup ini. Ayat pertama yaitu ayat-ayat yang berasal dari al-Qur'an itu sendiri yang lebih dikenal sebagai ayat-ayat naqliyyah. Pada saat yang bersamaan terdapat ayat lain yang hendaknya dipelajari dan dipahami dalam bentuk bentangan alam semesta. Inilah ayat yang lebih dikenal sebagai ayat-ayat kauniyyah. Sebagaimana ayat-ayat naqliyyah yang memiliki berbagai lapisan makna serta tafsir, dari mulai yang paling harfiyyah (lahir) maupun sampai ke dalam lapisan terdalam dari ayat itu (makna batin). Pun demikian dengan alam semesta. Ia menyimpan hierarki makna yang terbentang dari apa yang nampak sampai

${ }^{4}$ Ditelisik lebih jauh, sesungguhnya sumber ilmu pengetahuan adalah Allah, Sang Maha Pemberi Pengetahuan. Akan tetapi derajat hubungan antara manusia dan sumber ini berbeda antara satu manusia dengan yang lainnya. Sebagian orang berpikir tapi tidak menemukan kebenaran apaapa, sementara ada yang lain yang menemukan kebenaran melalui perenungan. Proses pencarian ilmu pengetahuan tersebut tidaklah akan sampai kepada pengertian dan pemahaman yang komprehensif jika tidak bersumber dan berakhir kepada Allah SWT. Inilah maksud dari perkataan mencari jejak-jejak Tuhan dalam sains. Baca Mehdi Golshani. Melacak Jejak Tuhan dalam Sains. Terj. Ahsin Muhammad. Bandung: Mizan, 2004, hal. 34 atau Mehdi Golshani, Filsafat Sains menurut Al-Qur'an. Terj. Agus Effendi. Bandung: Mizan, 1998, hal. 40. 
ke makna yang paling tersembunyi. ${ }^{5}$ Itulah alasan yang melandasi bahwa ilmu pengetahuan di dalam Islam memiliki makna yang juga bertingkat-tingkat. Allah berfirman dalam Surat Ali 'Imran (QS: 190 - 191).

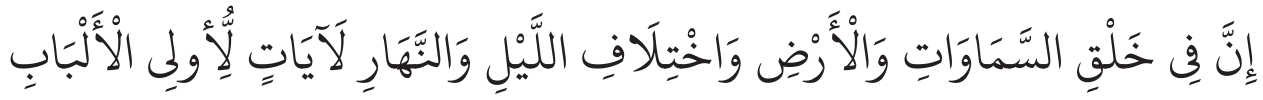

Artinya: "Sesungguhnya dalam penciptaan langit dan bumi, dan silih bergantinya malam dan siang terdapat tanda-tanda bagi orang-orang yang berakal."

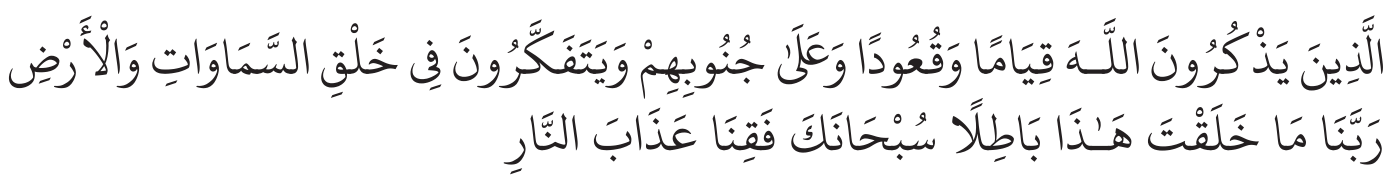

Artinya: "(yaitu) orang-orang yang mengingat Allah sambil berdiri atau duduk atau dalam keadan berbaring dan mereka memikirkan tentang penciptaan langit dan bumi (seraya berkata): "Ya Tuhan kami, tiadalah Engkau menciptakan ini dengan sia-sia, Maha Suci Engkau, maka peliharalah kami dari siksa neraka.

Nampak jelas di dalam kedua ayat tersebut bahwa alam semesta tidak mungkin diciptakan oleh Allah SWT dengan sia-sia. Ia merupakan tanda bagi hamba-hamba-Nya yang berpikir. Berbagai fenomena alam yang terjadi merupakan tanda akan kebesaran Allah SWT yang mendorong rasa iman di hati, sekaligus pada saat yang bersamaan mendorong keingintahuan diri untuk mengenal lebih jauh hukum-hukum alam yang terdapat pada fenomena tersebut.

Di dalam Islam, metafisika menduduki posisi ilmu pengetahuan yang sangat penting. Ia berada dalam posisi pertama sebelum logika, matematika maupun fisika. Metafisika inilah yang akan menjadi asal lahirnya berbagai ilmu pengetahuan, sehingga ia tidak akan kehilangan arah dan orientasi sebagaimana biasanya terjadi dalam tradisi ilmu pengetahuan di dunia Barat. Sebagai sumber ilmu pengetahuan, metafisika ini hanya dapat disingkapkan melalui ilmu huduri (knowledge by presence). Ilmu in sesuai dengan ungkapan "man 'arafa nafsahu

${ }^{5}$ Hierarki ilmu pengetahuan bersumber dari realitas itu sendiri yang memang hierarkis. Realitas tertinggi yaitu Allah SWT yang dari-Nya kita lahir dan kepada-Nya kita kembali (inna lillâhi wa inna ilaihi râjiûn). Konsep tawhid menjadi signifikan karena terkait dengan pengembangan ilmu pengetahuan itu sendiri serta klasifikasinya. Ilmu tentang Allah tentu menduduki posisi yang paling tinggi bila dibandingkan dengan ilmu-ilmu lainya. Silahkan baca Osman Bakar,. Tauhid \& Sains. Terj. Yuliani Liputo \& M.S. Nasrulloh. Bandung: Pustaka Hidayah, 2008, hal. 68. 
fa qad 'arafa rabbahu" yang artinya, "barang siapa yang mengenal dirinya maka niscaya ia akan mengenal juga Tuhannya."

Ilmu selanjutnya yang menjadi fokus dari Islam yaitu ilmu matematika dan logika. Ilmu matematika dan logika merupakan ilmu pengetahuan yang terhubung langsung dengan metafisika. Ilmu matematika dan logika berupaya untuk memahami hukum matematis dalam alam pikir dan alam semesta. Hukum-hukum tersebut terdapat dalam alam pikir manusia. Maksud dari kedua ilmu tersebut yaitu untuk mengetahui hukum berpikir secara objektif dan tentunya benar. ${ }^{7}$

Ilmu fisika merupakan jenis ilmu pengetahuan lain yang dikembangkan, bahkan di dorong oleh al-Qur'an. ${ }^{8}$ Ilmu fisika ini dikembangkan untuk mengetahui bagaimana hukum alam secara objektif sebenarnya berjalan. Dengan mengetahui hukum alam tersebut, berbagai kesulitan yang lahir dari ketidaktahuan akan hukum alam dapat teratasi. Metafisika, matematika, logika dan fisika merupakan ilmu-ilmu teoritis yang didorong pengembangannya oleh al-Qur'an. Dengan ilmu-ilmu teoritis ini diharapkan umat Islam dapat mengenal segala sesuatu sebagaimana adanya (das ding an sich). Di dalam Islam, ilmu-ilmu teoritis ini berada lebih dulu jauh sebelum ilmu-ilmu praktis seperti etika, ekonomi dan politik berkembang.

Al-Qur'an pernah menggambarkan dengan sangat gamblang bagaimana alam semesta tunduk (taskhîr) dan pasrah sebenarnya kepada manusia. Allah berfirman dalam Surat al-Jaatsiyah (QS: 13).

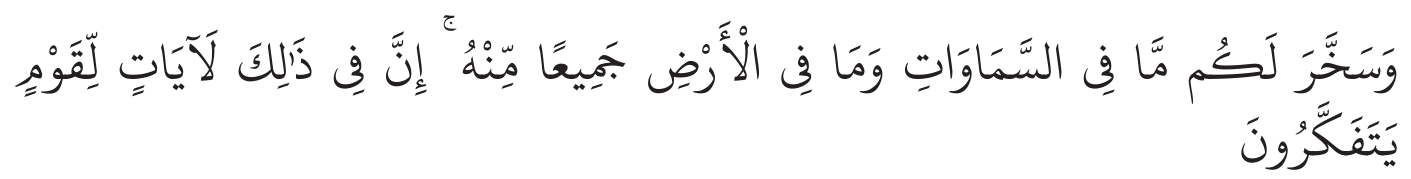

Artinya: "Dan Dia telah menundukkan untukmu apa yang di langit dan apa yang di bumi semuanya, (sebagai rahmat) daripada-Nya. Sesungguhnya pada yang demikian itu benar-benar terdapat tanda-tanda (kekuasaan Allah) bagi kaum yang berfikir."

Demikianlah al-Qur'an menekankan peran yang sangat penting terkait keistimewaan manusia. Alam semesta yang terbentang begitu luas tunduk dan

\footnotetext{
${ }^{6}$ Osman Bakar,. Tauhid \& Sains. Terj. Yuliani Liputo \& M.S. Nasrulloh. Bandung: Pustaka Hidayah, 2008, hal. 91.

${ }^{7}$ Achmad Baiquni, Al-Quran dan Ilmu Pengetahuan Kealaman. Yogyakarta: PT. Dana Bhakti Prima Yasa, 1996, hal. 21.

${ }^{8}$ Achmad Baiquni, Al-Quran dan Ilmu Pengetahuan Kealaman. Yogyakarta: PT. Dana Bhakti Prima Yasa, 1996, hal. 43.
} 
patuh (taskhîr) kepada manusia. Di tangan manusia-lah masa depan alam semesta sesungguhnya. Sebagai co-partner Tuhan, manusia diminta untuk senantiasa menebarkan kebaikan di manapun berada. Ia bertanggungjawab langsung akan berbagai kerusakan di atas muka bumi. Sebaliknya juga demikian, berkat manusia jugalah alam semesta dapat terus dipelihara, dilestarikan dan dikonservasi menjadi alam yang memang layak untuk dihuni oleh umat manusia.

\section{Sains dan Teknologi dalam Tradisi Islam}

Jauh sebelum peradaban Barat mengembangkan sains dan teknologi sekaligus berbagai turunannya, para ilmuwan Islam sudah terlebih dahulu mengembangkan banyak terobosan dan inovasi terkait sains dan teknologi. Misalnya di bidang matematika, setidaknya masyarakat Islam sudah mewarisi tiga sistem perhitungan sekaligus, yang pertama mengunakan metode susunan-jari dengan menunjukkan angka-angka berdasarkan posisi jari-jari, yang kedua dari Babilonia yang menunjukkan bilangan dengan sembilan angka dan satu simbol, kosong yang disebut sifr atau nol. Sistem bilangan ketiga berasal dari India. Al-Khawarizmi, seorang ahli matematika yang lahir di Persia pada abad ke-8, mampu mengalihkan angka-angka Hindu dan Babilonia ke dalam sistem yang sangat sederhana dan dapat diterapkan oleh semua orang. Ia telah mampu melahirkan 'aljabar' maupun algoritma berikut konsep-konsep yang di belakangnya. ${ }^{9}$

Di bidang astronomi, masyarakat Islam sudah memberikan sumbangan yang tidak terhingga banyaknya. Masyarakat Islam menciptakan Zij yang merupakan buku pegangan yang berisi sekitar 200 halaman tabel yang isinya banyak terkait dengan masalah-masalah astronomi ruang, termasuk penentuan waktu dari ketinggian matahari dan juga menentukan arah matahari. Tabel tersebut digunakan juga untuk menentukan waktu-waktu shalat berdasarkan derajat longitudinal matahari.Masyarakat Islam juga membangun pusat-pusat penelitian dan observatorium yang digunakan untuk melihat fenomena langit angkasa seperti Observatorium Besar di Samarkand, Uzbekistan. ${ }^{10}$

Di dalam bidang fisika dikenal tokoh besar Islam seperti al-Biruni misalnya yang sudah memberikan sumbangan penting bagi pengukuran berat jenis (specific gravity) berbagai zat dengan hasil perhitungan yang cermat dan akurat. Sumbangan besar lainnya yaitu metode dan eksperimen yang dia gunakan cukup mudah dan tepat sehingga tetap terpakai sampai saat ini. Dia merancang piknometer, yaitu suatu alat untuk menentukan berat jenis cairan berupa gelas

${ }^{9}$ Howard R Turner, Sains Islam Yang Mengagumkan Sebuah Catatan terhadap Abad Pertengahan. Terj. Zulfahmi Andri. Bandung: Nuansa, 2004, hal. 57.

${ }^{10}$ Howard R Turner, Sains Islam Yang Mengagumkan Sebuah Catatan terhadap Abad Pertengahan. Terj. Zulfahmi Andri. Bandung: Nuansa, 2004, hal. 97. 
bulat. Al-Khazini adalah sosok lainnya yang sudah berhasil mencatat gravitasi tertentu pada benda padat dan cair, namun juga membentuk standar pengukuran, neraca, dan mengajukan teori-teori tentang sistem kapiler dan sistem pengungkit sederhana. Tulisan yang berjudul Kitab Mizân al- $\underline{H} i k m a h$ ini kemudian menjadi rujukan standar di Eropa Abad Pertengahan. ${ }^{11}$

Di bidang kedokteran, sudah banyak kontribusi yang diberikan oleh ilmuwan Muslim pada saat itu. Mulai dari al-Razi yang mengembangkan dua model dokter sekaligus yaitu dokter klinis dan dokter ruhani. Ibn Sina yang dikenal sebagai "pangeran para dokter" sudah menuliskan banyak sekali karya mengenai bidang kedokteran. Abu al-Qasim al-Zahrawi dikenal sebagai dokter ahli bedah dan Ibnu Nafis yang dikenal sebagai penemu kapiler paru-paru. ${ }^{12}$

Di bidang kimia terdapat Jabir Ibn Hayyan, seorang sufi sekaligus ahli kimia. Jabir Ibn Hayyan menyumbangkan banyak sekali teori kimia seperti penguapan, persenyawaan, pembutiran, pelelehan dan sublimasi. Salah satu teori Jabir tentang sulfur-air raksa menjadi cikal bakal lahirnya teori kimia modern yaitu teori asam-basa. Sebagai bukti bahwa masyarakat Islam pernah menjadi pelopor di bidang ini dapat diketahui dari berbagai penggunaan bahasa Arab dalam istilah teknologi kimia modern seperti alambique, alchemy, alcohol, azimuth, elixir, henna, nadir, saffron dan lain-lainnya. ${ }^{13}$

Masyarakat Islam pada masa klasik terbukti dengan jelas telah memberikan kontribusi besar bagi pengembangan teknologi. ${ }^{14}$ Posisi mereka pada masa itu jauh unggul di atas peradaban lainnya. Ibn Taymiyyah pernah memberikan gambaran kondisi pada masa itu:

"Kaum Muslimin mengembangkan berbagai ilmu pengetahuan baik yang bersifat kenabian (agama) maupun rasional, yang juga pernah dikembangkan oleh umat-umat sebelumnya. Tapi mereka, orang-orang Muslim itu, memiliki keunggulan dengan ilmu pengetahuan yang tidak dipunyai oleh umat-umat yang lain. Ilmu pengetahuan rasional dari umat-umat lain yang sampai ke tangan orang-orang Muslim kemudian dikembangkan, baik pengungkapan maupun isinya, sehingga menjadi lebih baik daripada yang ada pada umat-umat lain itu, kemudian dibersihkan dari patokan-patokan yang palsu, dan ditambahkan ke-

\footnotetext{
${ }^{11}$ Husain Heriyanto, Menggali Nalar Saintifik Peradaban Islam. Bandung: Mizan, 2011, hal. 259.

${ }^{12}$ Husain Heriyanto, Menggali Nalar Saintifik Peradaban Islam. Bandung: Mizan, 2011, hal. 191.

${ }^{13}$ Husain Heriyanto, Menggali Nalar Saintifik Peradaban Islam. Bandung: Mizan, 2011, hal. 181.

${ }^{14}$ A.I Sabra, dkk. Sumbangan Islam kepada Sains \& Peradaban Dunia. Bandung: Yayasan Nuansa Cendekia, 2001, hal. 1.
} 
padanya unsur kebenaran sehingga orang-orang Muslim itu menjadi lebih unggul daripada orang-orang lain." ${ }^{15}$

\section{ICT di Dunia Islam: Studi Kasus}

Islam merupakan agama dengan jumlah pengikut terbesar di dunia. Tercatat umat Islam di dunia sebesar 2,1 milyar jauh di atas umat lainnya, termasuk Protestan dan Katolik. Sebagai agama mayoritas, tentu perubahan apapun yang terjadi di dalam ilmu pengetahuan akan berpengaruh sangat signifikan bagi perkembangan umat Islam di dunia, termasuk di dalamnya perkembangan teknologi informasi.

Terkait dengan ICT (Information \& Communication Technology) merupakan turunan dari applied science itu sendiri. Ilmu pengetahuan (sains) terdiri dari dua jenis yaitu sains murni (pure science) dan sains terapan (applied science). Sains murni terdiri dari kimia, fisika dan biologi. Orientasi dari sains murni adalah mengetahui bagaimana hukum alam bekerja apa adanya (das ding an sich). Berbeda halnya dengan ilmu-ilmu terapan di mana orientasi dari ilmu terapan adalah bagaimana ilmu tersebut dapat secara praktis diterapkan dalam kehidupan sehari-hari umat manusia. Kebutuhan pragmatis sangat kuat dalam ilmu terapan ini. Kemaslahatan hidup manusia menjadi orientasi tertinggi ilmuilmu terapan tersebut. Contoh dari ilmu terapan yaitu teknologi, kedokteran termasuk ICT di dalamnya. Sebagai ilmu terapan, ICT amat sangat mungkin dapat digunakan oleh umat Islam guna mendukung kehidupan beragama yang lebih baik di masa mendatang. Demi kebutuhan itulah titik temu antara Islam dan sains dapat dilakukan. ${ }^{16}$

ICT berbasiskan kepada internet dengan melewati tiga pola dan menggabungkannya sekaligus yaitu pengetahuan (knowledge), informasi (information) dan data itu sendiri. Sekumpulan data yang dihasilkan lewat proses $\mathrm{hu}$ man invention tersebut akan melahirkan jenis pengetahuan baru yaitu knowledge based management (KBM). Informasi yang begitu melimpah, dapat diatur dengan sedemikian hingga sehingga memudahkan bagi kita untuk memanfaatkannya. Sebagai contoh misalnya, UIN Syarif Hidayatullah Jakarta sedang mengembangkan sebuah website al-Qur'an yang berbasiskan pada KBM ini. Pembuatan database yang sangat terstruktur ini akan membantu bagi kita yang sedang mencari ayat-ayat al-Qur'an untuk menemukan kata-kata padanan atau tafsir dari masing-masing ayat yang ada. Proyek www.corpusquran.com dapat

${ }^{15}$ Budhy Munawar-Rachman, Ensiklopedi Nurcholish Madjid. Jakarta: Teraju, 2005, hal. 3241.

${ }^{16}$ Ringkasan kuliah yang disampaikan oleh Dr. Syofiansyah Jaya Putra dalam matakuliah Religion and Science di UIN Syarif Hidayatullah Jakarta pada 13 September 2016. 
dijadikan contoh bagaimana kecanggihan teknologi informasi dapat disatukan dengan keinginan untuk menghadirkan data yang mumpuni terkait al-Qur'an. Sebagai teknologi baru, ICT membutuhkan data sebagai sumber utama serta media komunikasi yang canggih. Berbagai multimedia dapat juga digunakan untuk menambah kualitas ICT yang dikembangkan. Multimedia yang menggabungkan data, suara, gambar dan video dapat dijadikan sebagai sarana untuk menyampaikan informasi yang sudah disusun, dalam hal ini informasi terkait al-Qur'an, terjemahan dan tafsirnya. ${ }^{17}$

Terkait dengan komunikasi itu sendiri, itu merupakan bagian dari ajaran Islam untuk melakukan aktivitas iqra’ alias membaca di manapun dan kapanpun. Jadi membaca tidak berhenti hanya pada teks buku saja, melainkan bisa terus dimaksimalkan untuk membaca apa saja, termasuk di dalamnya informasi-informasi yang ada di dalam media sosial.

Di dalam proyek www.corpusquran.com juga terdapat satu item terkait dengan search engine atau mesin pencari ayat. Terkait dengan ayat-ayat yang akan dicari dapat dimaksimalkan pencariannya melalui mesin pencari ayat tersebut.

\section{Sebuah Tantangan}

Pemaksimalan pemanfaatan penggunaan ICT dalam Islam tentu menjadi PR (pekerjaan rumah) bersama umat Islam. Beralih merujuk al-Qur'an yang berdasarkan web based tentu membutuhkan waktu untuk pembiasaannya (habituasi), jadi personal bukan hanya transfer of knowledge semata melainkan sudah masuk kepada wilayah budaya juga. Jadi karena perubahan tersebut membutuhkan proses, maka dalam pelaksanaannya pun membutuhkan kesabaran. Tidak semua orang ingin cepat beralih kepada perkembangan teknologi baru. Masih banyak yang kerasan dan betah untuk menggunakan sistem teknologi yang konvensional.

Persoalan lain yang tidak dapat diabaikan adalah kesiapan umat Islam sendiri ketika menerima banjir informasi tersebut. Setidaknya umat Islam harus bisa memilih dan memilah berbagai macam informasi yang diterima, baik secara langsung maupun tidak langsung. Jika tidak, maka teknologi informasi hanya akan menjadikan dan pendorong dari perpecahan umat Islam itu sendiri. Sederhanyanya, kita perlu kedewasaan dan kebijaksanaan dalam penggunaan ICT tersebut. Demikian yang harus menjadi catatan dalam pengembangan ICT ke depannya.

${ }^{17}$ Ringkasan kuliah yang disampaikan oleh Dr. Syofiansyah Jaya Putra dalam matakuliah Religion and Science di UIN Syarif Hidayatullah Jakarta pada 11 Oktober 2016. 
Tantangan lainnya yang muncul yaitu dampak negatif dari teknologi digital (termasuk ICT) sebagaimana yang berkembang saat ini. Memang benar pada satu sisi memiliki dampak positif yang melimpah seperti memudahkan seseorang untuk mencari informasi dan berkomunikasi juga kegiatan ekonomi lainnya, seperti on-line shopping dan lain sebagainya. Pada saat yang bersamaan muncul generasi yang tidak saling mengenal satu dengan yang lainnya. Mereka akrab di dunia maya akan tetapi tidak pada realitas sebenarnya. Kehidupan yang sangat cepat tersebut melahirkan pribadi-pribadi yang kosong jiwanya. Untuk itu, sikap bijak dalam pengembangan ICT sangat diperlukan, karena tanpa itu manusia tidak lebih seperti robot yang diatur oleh sistem komputer itu sendiri. $[\mathrm{AR}]$

Wallâhu a’lamu bi al-shawwâb []

\section{Daftar Pustaka}

Baiquni, Achmad. Al-Quran dan Ilmu Pengetahuan Kealaman. Yogyakarta: PT. Dana Bhakti Prima Yasa, 1996.

Bakar, Osman. Tauhid \& Sains. Terj. Yuliani Liputo \& M.S. Nasrulloh. Bandung: Pustaka Hidayah, 2008.

Golshani, Mehdi. Melacak Jejak Tuhan dalam Sains. Terj. Ahsin Muhammad. Bandung: Mizan, 2004.

Golshani, Mehdi. Filsafat Sains menurut Al-Qur'an. Terj. Agus Effendi. Bandung: Mizan, 1998.

Heriyanto, Husain. Menggali Nalar Saintifik Peradaban Islam. Bandung: Mizan, 2011.

Lubis, Akhyar Yusuf. Filsafat Ilmu Klasik Hingga Kontemporer. Jakarta: Rajawali Pers, 2016.

Putra, Dr. Syofiansyah Jaya. Ringkasan Kuliah Religion and Science di UIN Syarif Hidayatullah Jakarta pada 13 September 2016.

Putra, Dr. Syofiansyah Jaya. Ringkasan matakuliah Religion and Science di UIN Syarif Hidayatullah Jakarta pada 11 Oktober 2016.

Qardhawi, Yusuf. Al-Qur'an Berbicara tentang Akal dan Ilmu Pengetahuan. Terj. Abdul Hayyie al-Kattani \& Irfan Salim. Jakarta: Gema Insani Press, 1998.

Rachman, Budhy Munawar, Ensiklopedi Nurcholish Madjid. Jakarta: Teraju, 2005.

Sabra, A.I. dkk. Sumbangan Islam kepada Sains \& Peradaban Dunia. Bandung: Yayasan Nuansa Cendekia, 2001.

Toffler, Alvin. The Third Wave, USA: Bantam Books, 1980.

Turner, Howard R. Sains Islam Yang Mengagumkan Sebuah Catatan terhadap Abad Pertengahan. Terj. Zulfahmi Andri. Bandung: Nuansa, 2004. 